\title{
カチオン界面活性剤を添加した酸性スズ電解浴
}

\author{
小浦 延 幸* ・向 正 夫*
}

\section{Acidic Bath for Tin Electrodeposition Containing Cationic Surfactant}

Nobuyuki KOURA and Masao MUKAI

An acidic bath of simple electrolyte composition for electrolytic refining of tin was investigated with the object of obtaining a tin deposit of good adhesion. The effects of the addition of cationic surfactants to the bath was studied and the behavior of these additives was discussed.

The results obtained were summarized as follows.

(1) A tin deposit of good adhesion was obtained from the bath composition of $0.1 \mathrm{~mol} / 1 \mathrm{SnCl}_{2}$ and $0.25 \mathrm{~N} \mathrm{HCl}$ at $60^{\circ} \mathrm{C}$. However, the optimum current density was very low as $0.16 \mathrm{amp} . / \mathrm{dm}^{2}$.

(2) When $0.5 \mathrm{~g} / 1$ dodecylpyridinium chloride was added to the bath of $0.1 \mathrm{~mol} / 1 \mathrm{SnCl}_{2}$ and $0.5 \mathrm{~N} \mathrm{HCl}$ at $60^{\circ} \mathrm{C}$, a tin deposit of good adhesion was obtained under high current density (2.4 amp. $\left./ \mathrm{dm}^{2}\right)$ and at high current efficincy (99\%),

(3) As the results of the studies on the effects of dodecylpyridinium chloride on the tin electrodeposition, the following conclusion was drawn.

(a) The additive is strongly polarized as $\mathrm{CH}_{3}\left(\mathrm{CH}_{2}\right)_{11}-\stackrel{\oplus}{\mathrm{N}}$ substituent.

(b) Adsorbed atom $\mathrm{N}$ is positioned in 6-member ring of plane structure.

\section{1. 緒言}

この研究では, 高電流密度のもとで密着性よくチ密な 電着スズを得るための簡単な液組成のスズ電解浴を開発 することを目標に，塩酸々性塩化スズ浴の基本浴組成と それへのカチオン界面活性剤添加の効果について検討し た。

従来スズはバンカ島あるいはマレー半島などで得られ る砂スズと称せられる鉣石から，乾式製錬によって容易 飞高品位のものが得られた事情から, 他の諸実用金属に 比較してスズの電解精鍊の研究はあまり行なわれなかっ た。しかし近年スズハク，スズ合金，電気メッキブリキ 用陽極などに純度の高いスズが要望され，一方資源的に も砂スズは漸次枯渴しつつあり, 諸般の世界情勢から も，品位の低い山スズを主体とする鉣石から純スズを製 錬することが必要となってきて, スズの電解精錬が重要 な課題となってきた。スズ電解精錬の電解浴としては, アルカリ浴の代表例には第 1 表のようなるのがあげられ るが,これらは酸性浴に比して密着性において幾分まさ

* 東京工業大学 (東京都目黑区大岡山)

Tokyo Institute of Technology
るほかは電流効率, 電着速度, 陽極溶解, 浴温, 浴の電 導性, 浴の安定性, 浴の価格いずれに拈いても劣ってい る。したがって実用浴としてはもっぱら第2表に示すよ 5な酸性浴が用いられているが，酸性浴からの電着面は 粗暴で密着性が悪い。概してスズは針状結晶となりやす く，これを抑えるためケイフッ酸, ニカワおよびクレゾ ール, クレゾールスルホン酸, あるいは硫酸ナトリウム などが配合されてき，著者の 1 人も硫酸ナトリウムを大 量に加えることを試みて小規模の電解精錬に好結果を得

第 1 表 アルカリ浴

\begin{tabular}{l|c|c|c}
\hline \multicolumn{1}{c|}{ 浴 組 成 } & $\begin{array}{c}\text { No. 1 } \\
(\mathrm{g} / l)\end{array}$ & $\begin{array}{c}\text { No. 2 } \\
(\mathrm{g} / l)\end{array}$ & $\begin{array}{c}\text { No. 3 } \\
(\mathrm{g} / l)\end{array}$ \\
\hline $\mathrm{Na}_{2} \mathrm{SnO}_{3} \cdot 3 \mathrm{H}_{2} \mathrm{O}$ & 90 & & 12 \\
$\mathrm{SnCl}_{2}$ & & 50 & \\
$\mathrm{CH}_{3} \mathrm{COONa} \cdot 3 \mathrm{H}_{2} \mathrm{O}$ & 15 & & \\
$\mathrm{NaOH}$ & 7.5 & 125 & 2 \\
$\mathrm{Na}_{2} \mathrm{SO}_{3}$ & & 75 & \\
$\mathrm{NaF}_{\text {borax }}$ & & & 4 \\
$\mathrm{H}_{2} \mathrm{O}_{2}$ & & & 1 \\
\hline \hline
\end{tabular}


第 2 表酸性浴

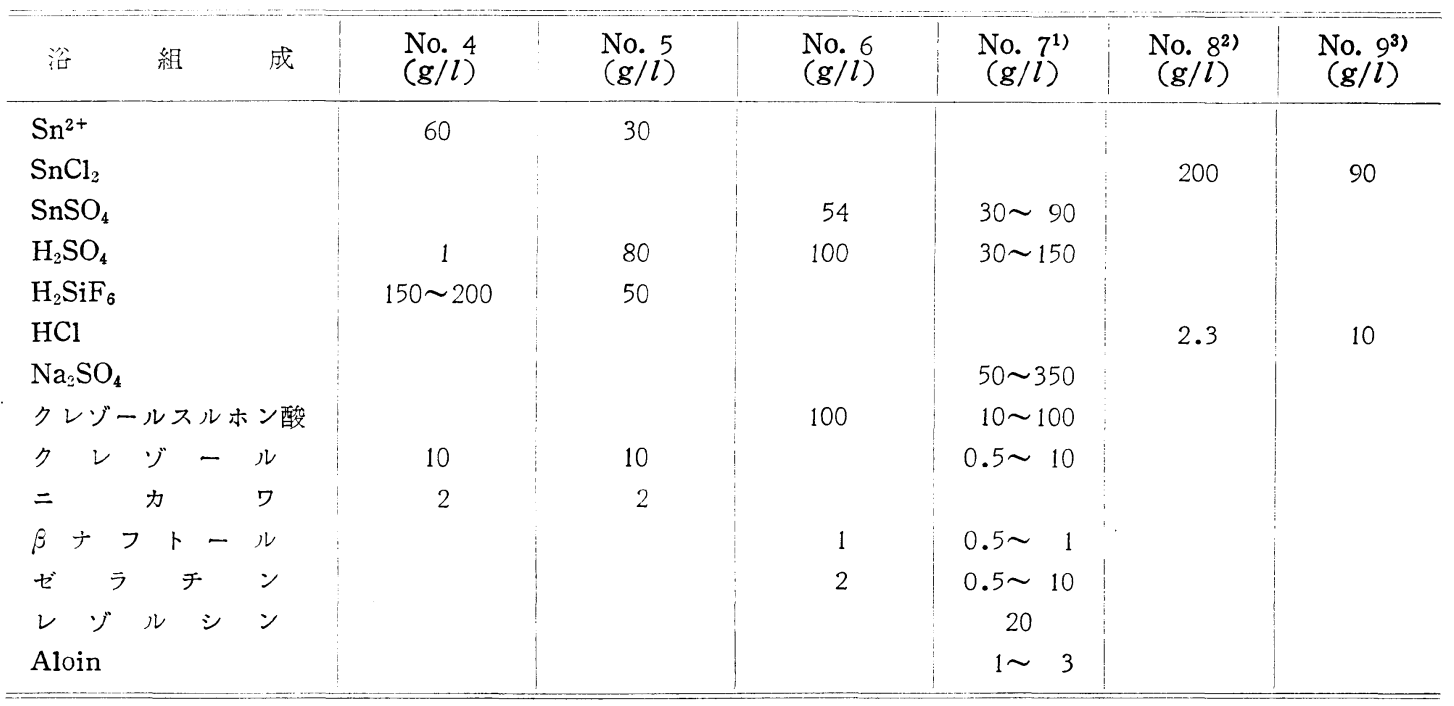

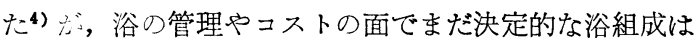
見出さ礼ていない。その他の各種添加剤飞ついても，土

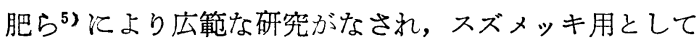
は工業的に成功しているものもあるが結局複雑な組成と なって晾り，またとくにカチオン界面活性剤に注目して の研究は見当らない上らである。

単純な酸性浴としては No. 8, No.9 のようと大量の $\mathrm{SnCl}_{2}$ を用いる浴が提案されて，よい電着スズを得たと 報告さ礼ており，筆者らむ陽極にスズアマルガムを用い $る^{6)}$ ことを考虑してこの塩酸々性塩化スズ浴飞注目す ることとしたが，一般にハロゲンイオンはスズの電着に 有害といわれて扣り7)，とく飞酸性塩化物浴では針状結 晶となる傾向方強い8)。したがって上では $\mathrm{SnCl}_{2}$ を大量 飞用いて非常飞濃い白濁液とすることとよって針状傾向 を抑觉ており，当然激しいカクハンを必要とし電流密度 も小さい。そこでこの研究では適当な添加剤を用いるこ ととよってこの浴の特徵を生かし，簡単な組成でしかも $\mathrm{SnCl}_{2}$ 濃度の低い安定な酸性浴を見出とうとした。すな わちスズは結晶成長速度が非常に速いため錫樹とよばれ る針状ないし樹脂状の結晶を呈し9，均一な電着となら ないので，結晶成長を抑觉て結晶核の発生を促すよう 飞, 結晶成長点すなわち活性点初飞選択的飞添加剤を吸 着させることとよって，その部分への電析を阻害させう る(1)なら均一平坦電着が可能となるであるらことを期待 して, $\mathrm{SnCl}_{2}-\mathrm{HCl}$ 系浴飞負電荷をもつ 固体表面飞強く 吸着する性質を有す ${ }^{-12}$ ) チオン界面活性剤の添加を試み ることとした。

\section{2. 実 験 方 法}

\section{2-1 電解装置および操作}

電解装置としては， $\pm 0.2^{\circ} \mathrm{C}$ と制御された恒温槽中に 電解槽を固定し，底に回転子を入れてマグネティックス ターラーで浴のカクハンを行なった。電解槽は $300 \mathrm{ml}$ ビ 一カーとし，30×40mm 陽極スズ板の間に同寸法の陰極 板を配置し，極間距離は30mmとした。陰極板には $18 / 8$ ステンレス板上にケイフッ酸浴でスズメッキしたものを 用い,電解前飞0，02，04，05番のエメリーペーパーで順 次研摩してのち,超微粒クレンザーで脱脂,水洗を行なっ た。電位測定には東亜電波製 $\mathrm{EPR}-2 \mathrm{~T}$ 型高感度記録計 を用い，また電気量測定とは銅電量計を使用したが，電 解時間はスズ電着量が約 $300 \mathrm{mg}$ になるよう調節した。電 解後ただちに陰極板を取り出して十分水洗し，アルコー ル洗浄の後乾燥空気で乾燥させ, 重量測定後オリンパス 金属顕微鏡 MF型で電着面の中央部を顕微鏡観察した。

\section{2-2 試薬および金属スズ}

試薬はすべて特級試薬を用い, 電解液調製には所定量 の $\mathrm{SnCl}_{2} \cdot 2 \mathrm{H}_{2} \mathrm{O}$ を所定量の $8 \mathrm{NHCl}$ 中に加えて完全に 溶解させ, 純水を加えて $300 \mathrm{ml}$ とした。これとカチオ ン界面活性剂を添加する際は，加温して完全に溶解させ た。また陽極に用いる金属スズとしては $99.99 \%$ 電気 Snを用いた。

\section{3. 実 験 結 果}

\section{3-1 $\quad \mathrm{SnCl}_{2}-\mathrm{HCl}$ 系浴}

まず $\mathrm{SnCl}_{2}-\mathrm{HCl}$ 系浴について, $\mathrm{SnCl}_{2}$ 濃度の低い範 囲すなわち塩酸々性溶液中に $\mathrm{Sn}^{2+}$ が安定に存在しらる 濃度範囲で,この浴の最適組成, 電流密度 (C.D. と略記)， 特よび浴温の検討を行なった。 


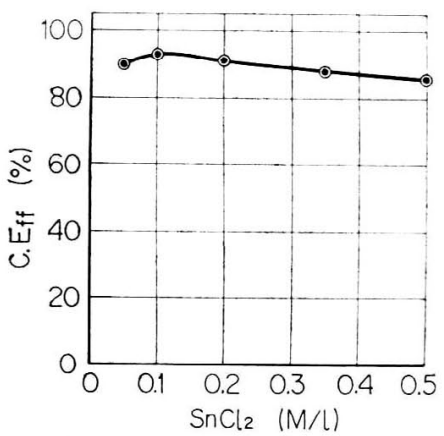

電解液 : $0.05 \sim 0.5 \mathrm{M} / l \mathrm{SnCl}_{2}+1.0 \mathrm{~N} \mathrm{NCl}$ C.D. : $0.16 \mathrm{~A} / \mathrm{dm}^{2}$, 浴温 : $60^{\circ} \mathrm{C}$

第 1 図塩化第一スズ浱度と電 流效率

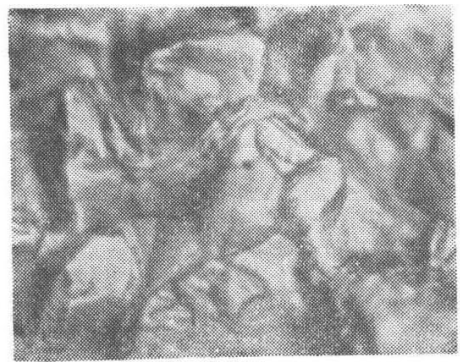

(a) C.D. : $0.16 \mathrm{~A} / \mathrm{dm}^{2}, \quad \times 600$

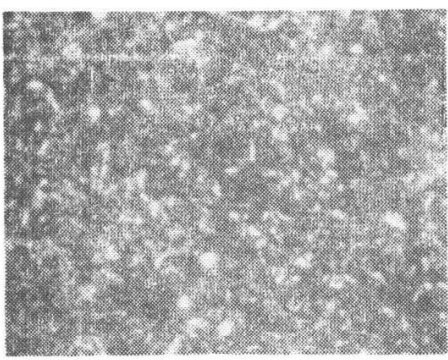

(c) C.D. : $0.24 \mathrm{~A} / \mathrm{dm}^{2}, \quad \times 150$

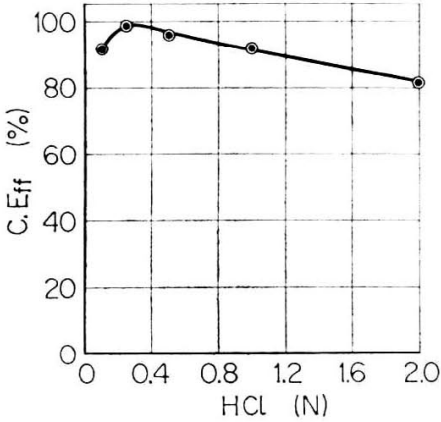

電解液 : $0.1 \mathrm{M} / l \mathrm{SnCl}_{2}+0.1 \sim 2.0 \mathrm{~N} \mathrm{HCl}$ C.D. : $0.16 \mathrm{~A} / \mathrm{dm}^{2}$, 浴温 : $60^{\circ} \mathrm{C}$

第 2 図塩酸濃度と電流效率

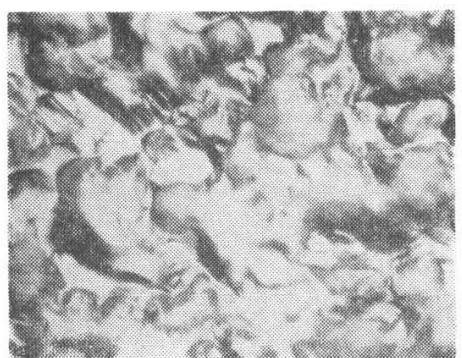

(b) C.D. : $0.24 \mathrm{~A} / \mathrm{dm}^{2}, \quad \times 600$

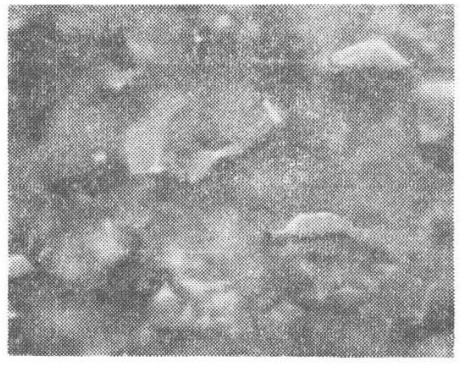

(d) $\mathrm{HCl}: 1.0 N$, C.D. $=0.16 \mathrm{~A} / \mathrm{dm}^{2} \times 600$

写真 $10.1 \mathrm{M} / l-\mathrm{SnCl}_{2}+0.25 N-\mathrm{HCl}$ 系浴のスズ電着面

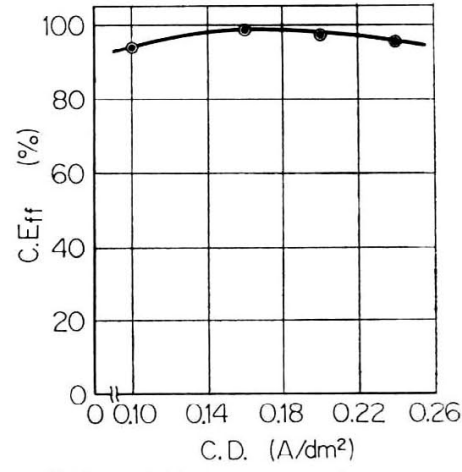

電解液 : $0.1 \mathrm{M} / l \mathrm{SnCl}_{2}+0.25 N \mathrm{HCl}$

C.D. : $0.10 \sim 0.24 \mathrm{~A} / \mathrm{dm}^{2}$, 浴温 : $60^{\circ} \mathrm{C}$

第3 図電流密度と電流效率

極の周辺部に針状結晶を生じ極 表面飞多少気泡の発生が見られ た。そのためC.Eff も低下する ものと思われる。これらの結果 から浴組成としては, $\mathrm{SnCl}_{2}$ 濃 度は $0.1 \mathrm{M} / l, \mathrm{HCl}$ 濃度は 0.25 $N$ とすることが適当と思われた な扔陽極溶解の C.Eff はいずれ の場合も常に 100\%であった。 3-1-2 電流密度抢よび浴温 上記の電解浴を用い最適C.D. 範用を検討した。その結果は第 3图のよ5飞 C.Eff は 0.16A/ $\mathrm{dm}^{2}$ 飞沶いて極大 $(99 \%)$ とな り，スズの電着状態は肉眼推 察でないずれの場合も非常に よく, $0.24 \mathrm{~A} / \mathrm{dm}^{2}$ となると極 の周辺部に小さな猃状結晶が見 られる程度であった。電着面の 顕微鏡観察飞よると，0.16 A/

\section{3-1-1 $\mathrm{SnCl}_{2}$ および $\mathrm{HCl}$ 濃度}

$\mathrm{HCl}$ 濃度は1.0Nと設定し, $\mathrm{SnCl}_{2}$ 濃度を変化させつつ スズ電着の電流効率(C.Eff と略記)を測定して, 第 1 図 のような結果を得た。C.Eff はいずれも $85 \%$ 以上である が， $0.1 \mathrm{M} / l$ 付近で極大 $(93 \%)$ を示し, $0.5 \mathrm{M} / l$ 以上では 電解中に $\mathrm{Sn}^{4+}$ の加水分解による白濁が認められた。な拉 $0.05 \mathrm{M} / l$ 以下では急激にスズの電着状態が悪くなった。 そこで $\mathrm{SnCl}_{2}$ 濃度は0.1 M/lとすることとし, $\mathrm{HCl}$ 濃度を 変化させつつC.Effの测定を行ない,第2図のような結果 を得た。この場合は $\mathrm{HCl} 0.25 N$ 付近でC.Effは明膫に極 大 $(99 \%)$ 宗し， $2.0 N$ では80\% と低下した。一方電着 状態については，0.1Nではやや粉状を呈し，0.25Nで 密着性のよい金属光沢を現わしたが，2.0 N そなると電 $\mathrm{dm}^{2}$ の場合 (写真1-(a)) 結晶は大きな成長ピラミッド 型であるが，ピラミッドの頂上と底部との高低差は0.5 前後で，この場合の電着層の厚サ約 $17 \mu$ に比してはるか に小さい。ところが $0.24 \mathrm{~A} / \mathrm{dm}^{2}$ の場合 (写真1一(b)) はピラミッド状からさらに電極面比刘し垂直方向への結 晶成長が盛んになり, 結晶面の高低差がはげしくなって デントライト結晶へすすを初期状態を思わせる。しかし この場合でも倍率 150 の写真 (写真 1-(c)) で示される よ5に, まだ密着性はよい。比較のため $\mathrm{HCl}$ 濃度 $1 N$, C.D. $0.16 \mathrm{~A} / \mathrm{dm}^{2}$ の場合を写真1一(d)飞示すが，結唱は 明らかとデントライト状に移行し, 結晶面の高底差は 2 〜3 となっている。これらのことより C. D. は 0.16 $\mathrm{A} / \mathrm{dm}^{2}$ が最適であると判断した。 
第3表 ス ズ 電 着 状 態

電解液 : $0.1 \mathrm{M} / l-\mathrm{SnCl}_{2}+0.5 N-\mathrm{HCl}+0.5 \mathrm{~g} / l$-界面活性剂

C.D. : $1.5 \mathrm{~A} / \mathrm{dm}^{2}$, 浴温 : $60^{\circ} \mathrm{C}$, カクハン: 200 r.p.m.

\begin{tabular}{|c|c|c|}
\hline 種 & カチオン 界 面 活 性 剂 & ス ズ 電 着 状 態 \\
\hline $\begin{array}{l}\text { 第ア } \\
\text { ¿ } \\
\text {-シ }\end{array}$ & オクタデシルアミンアセテート & $\begin{array}{l}\text { 電極全面を細い針状結晶の } \\
\text { かたまりか覆う }\end{array}$ \\
\hline \multirow{3}{*}{$\begin{array}{l}\text { 第 } \\
\text { 四 }\end{array}$} & $\begin{array}{l}\text { テトラメチルアンモニウムクロ } \\
\text { ライド }\end{array}$ & $\begin{array}{l}\text { 電極全面を大きな突起状結 } \\
\text { 晶が覆う }\end{array}$ \\
\hline & $\begin{array}{l}\text { トリメチルドデシル } \\
\text { アンモニウムクロライド }\end{array}$ & $\begin{array}{l}\text { 電極の半面に細い針状結晶 } \\
\text { が散在 }\end{array}$ \\
\hline & $\begin{array}{l}\text { トリメチルヘキサデシル } \\
\text { アンモニウムブロマイド }\end{array}$ & $\begin{array}{l}\text { 細い針状結晶, 上よりやや } \\
\text { 多い }\end{array}$ \\
\hline $\begin{array}{l}\text { ア } \\
\text { ン }\end{array}$ & $\begin{array}{l}\text { トリメチルオクタデシル } \\
\text { アンモニウムクロライド }\end{array}$ & 同 \\
\hline \multirow{2}{*}{$\begin{array}{l}モ \\
= \\
\text { ウ }\end{array}$} & ベンザルコニウムクロライド & $\begin{array}{l}\text { 電極全面を細い針状結晶が } \\
\text { 覆う }\end{array}$ \\
\hline & $\begin{array}{l}\text { ベンジルドデシル } \\
\text { アンモニウムクロライド }\end{array}$ & 上 \\
\hline \multirow[t]{2}{*}{ 么 } & ドデシルピリシニウムクロライド $\mathrm{CH}_{3}\left(\mathrm{CH}_{2}\right)_{11}-\mathrm{N}$ & $\begin{array}{l}\text { 針状結晶なし } \\
\text { 密着性常飞良好 }\end{array}$ \\
\hline & ドデシルピコリニウムクロライド $\mathrm{CH}_{3}\left(\mathrm{CH}_{2}\right)_{11}-\mathrm{N}$ & 上 \\
\hline
\end{tabular}

留 添 加 剂

$* \mathrm{R}$ は $\mathrm{C}_{8} \sim \mathrm{C}_{18}$ の混合物

ついで浴温の検討を行なったが， $70^{\circ} \mathrm{C}$ 以上では C.Eff が急激に低下し，また電着状態は $60 \sim 70^{\circ} \mathrm{C}$ に特いて最 も良好であったので, 最適浴温としては $60^{\circ} \mathrm{C}$ とるこ ととした。したがって以降の実験はすべて浴温 $60^{\circ} \mathrm{C}$ と た。

\section{3-2 カチオン界面活性剂の添加}

上記の最適電解液組成, 電解条件のもとに, 平坦で密 着性良好な電着スズが得られるが，C.D. が $0.16 \mathrm{~A} / \mathrm{dm}^{2}$ と非常に小さいことは電解精錬の実用浴として問題であ る。そこで C.D. を大きくする解決策として, 第 3 表に 示すような各種のカチオン界面活性剤添加の効果を検討 することとした。この場合予備実験によって $\mathrm{HCl}$ 濃度

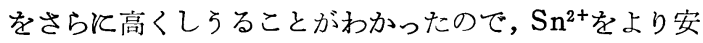
定に存在させるため $\mathrm{HCl}$ 濃度は $0.5 N$ とした。その結 果添加剤効果は第 1 アミンより第 4 アンモニウムの方が よく, 第 4 アンモニウムの5ちでは第 1 置換基が大きい ほど，また第 2 置換基が小さいほどよいことがわかっ た。とくにN原子を6 員環中に含み,第 2 置換基を有しな いドデシルピリジニウムクロライドがとくにすぐれた平 坦化効果を有していた (ドデシルピコリニウムクロライ ドについては後述)。な敃第 3 表の測定の際の自然電極

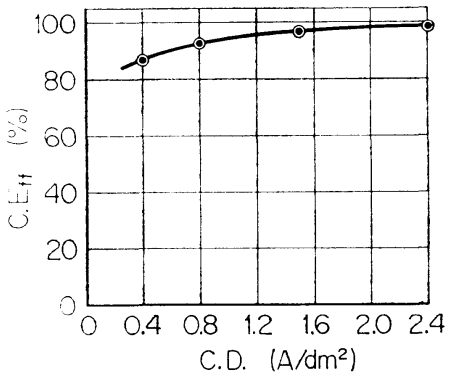

電解液 : $0.1 \mathrm{M} / l-\mathrm{SnCl}_{2}+0.5 N-\mathrm{HCl}+0.5 \mathrm{~g} / l-$ dodecylpyridinium chloride C.D. : $0.4 \sim 2.4 \mathrm{~A} / \mathrm{dm}^{2}$, 浴温: $60^{\circ} \mathrm{C}$, カクハン: 200 r.p.m.

第 4 図 ドデシルピリジニウムクロライド添加 浴の電流密度と電流効率

電位 (C.D. : 0) 执よび電解電位 (C.D. : $1.5 \mathrm{~A} / \mathrm{dm}^{2}$ ) の測定結果を第 4 表住す。

\section{3-3 ドデシルピリジニウムクロライド添加浴}

スズ電着のための添加剤としてはドデシルピリジニウ ムクロライドがすぐれていることが明らかとなったの で, $\mathrm{SnCl}_{2}$ 濃度は0.1M/ $l, \mathrm{HCl}$ 濃度は $0.25 N$ としてド デシルピリジニウムクロライドを $0.5 \mathrm{~g} / 1$ 添加した浴に 
第 4 表 自然電極電位招上び電解電位

\begin{tabular}{|c|c|c|}
\hline \multirow{2}{*}{ カチオン界面活性剤の吸着基 } & \multicolumn{2}{|c|}{ 電 位 (V vs. S.C.E.) } \\
\hline & $\mathrm{C} \cdot \mathrm{D} .=0$ & C.D. $=1.5 \mathrm{~A} / \mathrm{dm}^{2}$ \\
\hline 界面活 性郕なし & -0.538 & -0.543 \\
\hline 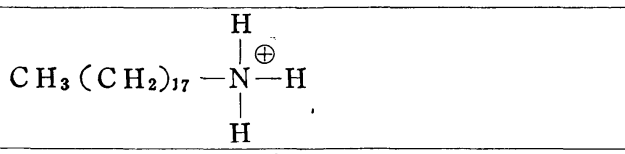 & -0.507 & -0.560 \\
\hline $\begin{array}{c}\mathrm{C} \mathrm{H}_{3} \\
\mathrm{CH}_{3}-\mathrm{N}-\mathrm{CH}_{3} \\
! \\
\mathrm{C} \mathrm{H}_{3}\end{array}$ & -0.493 & -0.509 \\
\hline 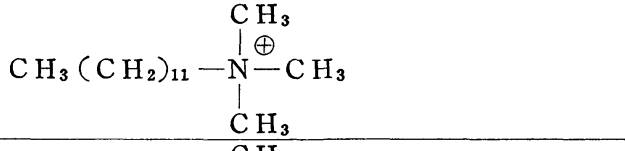 & -0.553 & -0.584 \\
\hline 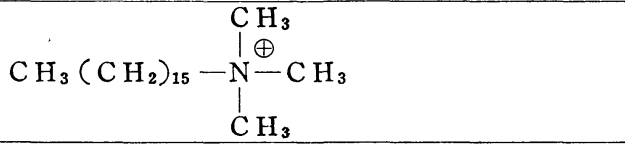 & -0.540 & -0.543 \\
\hline $\begin{array}{c}\mathrm{CH}_{3} \\
\mathrm{C} \mathrm{H}_{3}\left(\mathrm{CH}_{2}\right)_{17}-\underset{\mathrm{N}}{\stackrel{\oplus}{!}}-\mathrm{CH}_{3} \\
\mathrm{C} \mathrm{H}_{3} \\
\end{array}$ & -0.530 & -0.534 \\
\hline 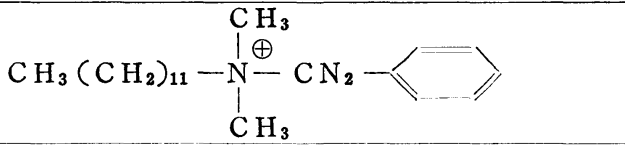 & -0.546 & -0.560 \\
\hline $\mathrm{CH}_{3}\left(\mathrm{CH}_{2}\right)_{11}-\mathrm{N}$ & -0.500 & -0.531 \\
\hline $\mathrm{CH}_{3}\left(\mathrm{CH}_{2}\right)_{11}-\stackrel{\oplus}{-} \longrightarrow \mathrm{CH}_{3}$ & -0.510 & -0.532 \\
\hline
\end{tabular}

ついて C.D.と C.Eff の関係を調べた（第 4 図)。この 場合 C. D. を非常飞大きくすることが可能となり， 2.4 $\mathrm{A} / \mathrm{dm}^{2}$ そ执いて C.Eff は最も高く $99 \%$ となり, 電着 状態もこのような高電流密度にもかかわらず電解時間 1 $\mathrm{h}$ (スズ電着量約 $1.2 \mathrm{~g}$ ) 後によ5やく電極の周辺部微 量の小針状結晶状態を呈する程度であった。な扔低電流 密度域で多少 C.Effが低下しているが, これは弱 HCl濃 度のため若干存在する $\mathrm{Sn}^{4+}$ の影響, あるいは添加剤 の強い吸着力による影響と思われる。一方スズ電着面の 顕微鏡観察では, $0.4 \mathrm{~A} / \mathrm{dm}^{2}$ の場合 (写真 2-(a)) 結晶 は電極面の水平方向に広がっていて, いわゆる塊状を呈 しており, 結晶核の密度が増加して電析物の粒度が細く なる ${ }^{11}$ 傾向を示している。0.8A/ $\mathrm{dm}^{2}$ の場合（写真 2- (b)）もほぼ同様であるが， $2.4 \mathrm{~A} / \mathrm{dm}^{2}$ (写真 2-(c)) で は結晶が小さくなるととると, わずかとピラミッド状の 結晶も散在し, 結晶飞高低差がはっきりと現われて, 垂 直方向への結晶成長（すなわちデントライト結晶への移 行) の傾向がわずかながら認められた。な特 $\mathrm{HCl} 0.5 \mathrm{~N}$ の場合は C.D. $0.8 \mathrm{~A} / \mathrm{dm}^{2}$ (写真3一(a)), $2.4 \mathrm{~A} / \mathrm{dm}^{2}$ (写 真3一(b)) いずれす $0.25 \mathrm{~N}$ の場合とほぼ同様の傾向を 示し, 高電流密度 $\left(2.4 \mathrm{~A} / \mathrm{dm}^{2}\right)$ ではむしろ $0.5 \mathrm{~N}$ の方 が結晶の高低差は小さくなっていて, 浴の安定性をも 考慮すれば $\mathrm{HCl}$ 濃度は $0.5 \mathrm{~N}$ の方がよいと判断され る。そこで $0.1 \mathrm{M} / l-\mathrm{SnCl}_{2}, 0.5 \mathrm{~N}-\mathrm{HCl}, 0.5 \mathrm{~g} / 1-$ dodecylpyridinium chloride なる電解浴を用い, 陰極 表面積を $120 \mathrm{~cm}^{2}$ とスケールアップし，1 A/ $\mathrm{dm}^{2}$ で $10 \mathrm{~h}$ 


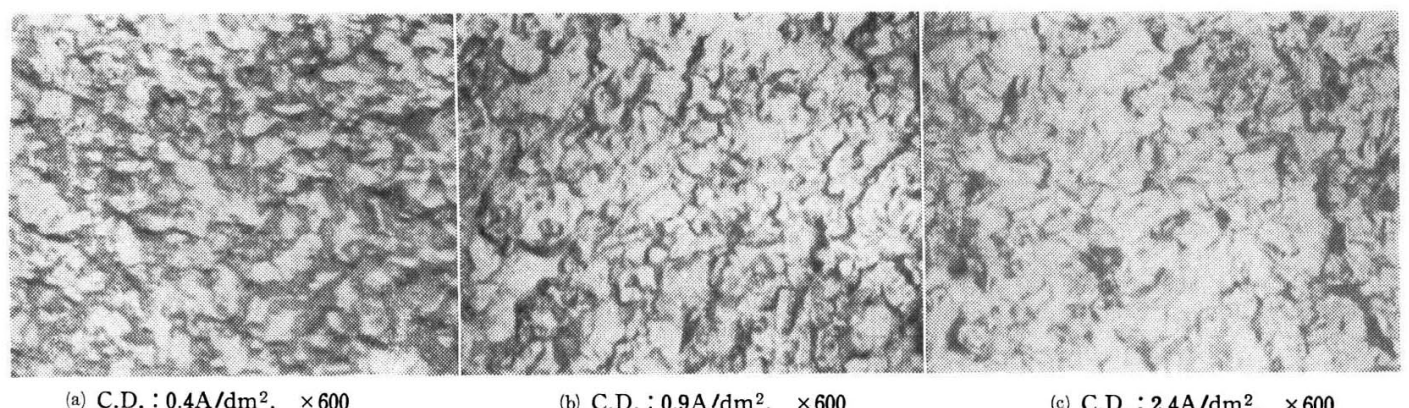

写真 $20.1 \mathrm{M} / l-\mathrm{SnCl}_{2}+0.25 N-\mathrm{HCl}+0.5 \mathrm{~g} / l$-dodecylpyridinium 系浴のスズ電着面

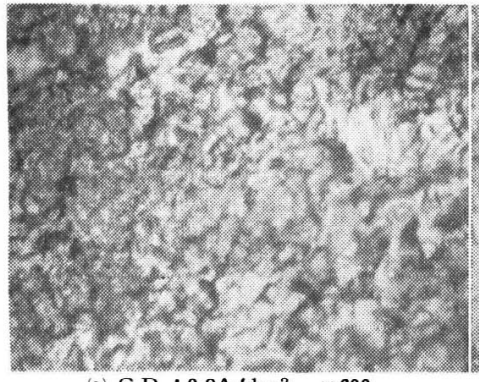

(a) C.D. : 0.8A/dm², $\times 600$

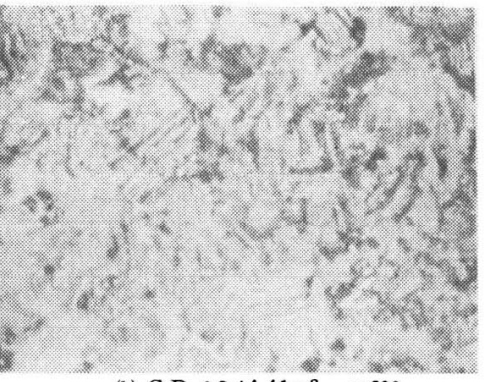

(b) C.D. : $2.4 \mathrm{~A} / \mathrm{dm}^{2}, \quad \times 600$

写真 $30.1 \mathrm{M} / l-\mathrm{SnCl}_{2}+0.5 N-\mathrm{HCl}+0.5 \mathrm{~g} / l-$ dodecylpyridinium chloride 系浴のスズ電着面

の電解実験を行なったところ，電着面は見事に平坦で針 状結晶が認められず, 密着性も良好であることを確かめ た。

な㸱これらの電解実験に持ける陽極のスズ溶解の

C.Eff は常に 100\%であった。

また第 3 表に打いて好結果の得られたドデンルピコリ ニウムクロライドについても検討を行なったところ，ド デシルピリジニウムクロライドと同様よい結果が得られ たな゙，2.4 A/ $\mathrm{dm}^{2}$ と高電流密度になると電極の周辺部に 針状結晶が認められ，平坦化效果忙多少劣ることがわか った。

\section{4. 考察}

金属面への界面活性剤の吸着垷象やその機作に関して は, 防食関係の研究の中で数多く取扱われているが，そ れらの解析の中には金属析出の平坦化機作と関連させる ことが可能なるのも少なくない11)。カチオン界面活性剤 は金属の負に帯電した部分にファンデルワース力によっ $\tau^{13)}$, あるいは金属との化学的結合力によって ${ }^{14)}$, 15) 吸 着するとされている。その吸着の効果については，吸着 力すなわち極性基の極性の強サ特よび化学結合力の強节 で表わされ，あるいはまた析出金属イオンの拡散を抑止 するのみならず界面での電気抵抗を増す効果 ${ }^{16) な と ゙ を も ~}$

有する有機基のしゃへい効果 ${ }^{17) て ゙ あ ~}$ 表わされている。そこでスズ電解浴 に添加剤として加えられたカチオン 界面活性剂の有効性およびその効果 の機作についてまずそれらの極性 の強サについて検討し，ついでしゃ へい効果をも含めた吸着效果につい て検討した。

な括ここで化学吸着についても考 虑しなければならないが，スズの化 学吸着に関する知見がそしく，また この祭は物理吸着の寄与の方がはる か㳄大いと考えられるので無視することとした。

\section{4-1 極性基の極性の強サ}

カチオン界面活性剤の極性基がもつ極性の強サは, 塩 基性解離定数または塩基度によって表わされる。たとえ ばアミンの場合

$$
\mathrm{R}_{3} \mathrm{~N}:+\mathrm{H}^{+} \mathrm{OH}^{-} \rightleftarrows \mathrm{R}_{3} \mathrm{~N}^{+}: \mathrm{H}+\mathrm{OH}^{-}
$$

なる解離反応に㧺いて，その解離定数 $(\mathrm{Kb})$ は

$$
\mathrm{Kb}=\frac{\left[\mathrm{R}_{3} \mathrm{NH}^{+}\right]\left[\mathrm{OH}^{-}\right]}{\left[\mathrm{R}_{3} \mathrm{~N}\right]}
$$

であり，塩基度 $(\mathrm{pKb})$ は

$$
\mathrm{pKb}=-\log \mathrm{Kb}
$$

である。第 1 ，第 2 ，第 3 アミンの中から数值例を示せ ば第 5 表のようで，有機基が大きいほど極性も強く，そ れは第 2 , 第 3 置換基について子肯定される。またアミ ンの種類については，第1アミンより第 2 アミンの方が 強いが，第 3 アミンでは立体障害等が生じて第 1 アミン

第 5 表 塩 基 度 $\left(25^{\circ} \mathrm{C}\right)^{18)}$

\begin{tabular}{l|l|l|l}
\hline $\mathrm{CH}_{3} \mathrm{NH}_{2}$ & 3.37 & $\mathrm{C} \mathrm{H}_{3} \mathrm{C} \mathrm{H}_{2} \mathrm{~N} \mathrm{H}_{2}$ & 3.27 \\
$\left(\mathrm{CH}_{3}\right)_{2} \mathrm{NH}$ & 3.22 & $\left(\mathrm{C} \mathrm{H}_{3} \mathrm{C} \mathrm{H}_{2}\right)_{2} \mathrm{~N} \mathrm{H}$ & 2.89 \\
$\left(\mathrm{CH}_{3}\right)_{3} \mathrm{~N}$ & 4.20 & $\left(\mathrm{CH}_{3} \mathrm{C} \mathrm{H}_{2}\right)_{3} \mathrm{~N}$ & 3.36 \\
\hline
\end{tabular}


よりる弱くなる。このような傾向は Hackerman ${ }^{19)}$ ， あ

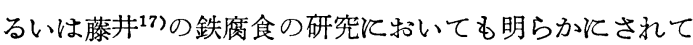
いる。また第 4 アンモニウムとついては， $\left[\mathrm{R}_{4} \mathrm{~N}\right]^{+} \mathrm{OH}^{-}$ の $\mathrm{pKb}$ は 0 であり, $\left[\mathrm{R}_{4} \mathrm{~N}\right]^{+} \mathrm{X}^{-}$はこの強塩基と強酸 の塩であるから，第 4 アンモニウムは非常に強い極性を 有すると考兄られる。第 1 アミンと第4アンモニウムと いずれの極性が強いかは直接定量的に明らか沉できない が，Hackerman ら ${ }^{19)}$ 亿よれば第4 アンモニウムの方が はるか強く吸着するといら結果が得られている。した がって第 3 表の実駼結果に扔いて，第 1 アミンよりも第 4フンモニウムの方がよい結果の得られた事実がうなず ける。しかし添加剤の効果を単に極性基の強サからだけ で説明しょうとすると，極性の強サと添加剤としての効

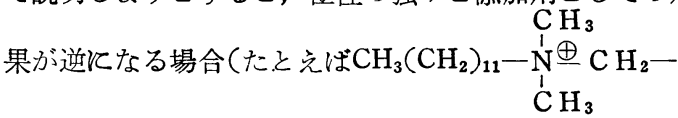
$\mathrm{C} \mathrm{H}_{3}$

$-N_{1}^{\dagger} \stackrel{\oplus}{-} \mathrm{CH}_{3}$ を対比)，あるいは $\mathrm{CH}_{3}$

極性の強サとはほとんど差はないのと添加剤効果に差の 出る場合(たとえばCH $\left(\mathrm{C} \mathrm{H}_{2}\right)_{11}-\stackrel{\oplus}{\mathrm{N}}=$ 明不可能となり，そこで他の作用の導入が必要となる。

\section{4-2 吸着効果}

添加剤が吸着効果(電着面の平坦化効果)を現わすため そは,しゃへい効果をも考虑に入れて,前述のようにスズ 電着面の活性点治く吸着してスズの結晶成長を抑える 必要がある。すなわち強いスズの垂直方向への結晶成長 を抑えると十分なだけ強く添加凨が吸着していることが 必要で，そこでその吸着効果の機作としては添加剤の極 性の強サに加えて，さらにその極性基の構造にも考慮を 払った考察が必要と考えられる。そのためカチオン界面 活性剤を添加した浴について，電位的な検討をも行なっ た。

第 4 表《招いて通電流 0 の場合，第 1 アミンのオクタ デシルアミン基，小さな置換基しか持たないテトラメチ

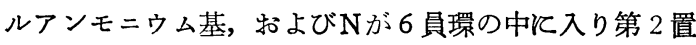
換基を持たないドデシルピリジニウム基などを添加した 際の電位は -0.493 -0.507V であり，その他 (ドデ シルピコリニウム基は除く）の場合のー0.530〜 -0.553 $\mathrm{V}$ と比較してかなり貴となっている。前者の場合は添加 剤の吸着によって金属スズの酸への溶解, したがって $2 \mathrm{H}^{+}+2 \mathrm{e} \rightarrow \mathrm{H}_{2}$ なる 反応が抑制されて自然電極電位は 貴となり ${ }^{19)}$ ，後者の場合は第 2 置換基などによる立体障 害14), 20) あるいは隣接分子への干涉 ${ }^{21}$ 等によってスズの 溶解すなわち $\mathrm{H}_{2}$ の発生を抑制することができず，無添 加剤浴の自然電極電位 $-0.538 \mathrm{~V}$ 亿近い早な電位を示す あのと推定される。このような置換基の影響については,
極性の增加とよる影響と，第4フンモニウム（Nが鎖中 そある場合) が 4 面体構造をとるためとくに顕著となる 立体障害等による影響との 2 つの相反する作用機作が考 えられる。第 1 置換基が $\mathrm{C}_{12}-, \mathrm{C}_{16}-, \mathrm{C}_{18}$ - でその他 の置換基がいずれるメチル基である場合は, 自然電極電 位も電解電位もこの順序で貴となり, 第 1 置換基の大き いほど吸着力も強〈なる ${ }^{22)}$ とい5傾向を示している。こ れは第 3 表の電着状態を観察した結果て执いても肯定さ れる。しかし第 2 置換基が ったベンジル゙デシルフンモニウム基の場合の自然電極 電位はー0.546Vで, 極性の強サから見れば上述の $\mathrm{C}_{16}-$ の場合にほぼ匹敵することが示唆されるが，電解電位は はるか禆となり， - $\mathrm{CH}_{2}$ 一基の立体障害等の 影響が見われていることを示している。このような考え のもとに, 第 2 置換基を持たないオクデシルアミン基, ドデシルピリシニウム基, および置換基がいずれる小さ いテトラメチルアンモニウム基などを添加した浴ではい ずれも自然電極電位が貴となることを説明しうるが，立 体障害を考慮するのみでは吸着効果を十分飞明らがす ることはできない。すなわち前 3 者のうち C.D. 1.5A/ $\mathrm{dm}^{2}$ で効果的な添加剤として顕著な作用が認められたの は, 第3 表に示すようにドデシルピリジニウム基のみで あった。オクタデシルアミン基添加のとさの電解電位は -0.560V と非常飞卑で,スズ電着る針状結晶となりその 吸着力がスズの結晶成長を抑觉るほど強くないことがわ かる。しかしテトラメチルアンモニウム基添加のときは， 電解電位が $-0.509 \mathrm{~V}$ と最も貴でありながら電着面が突 起状結晶になるという特異な現象が現われる。このよう な場合は吸着分子の溶液中での動きやすさに対して考虑 を払 ${ }^{16), 1^{99}}$ とともに，その吸着力はあまり強くないが電 極全面を弱く覆っているためと考えることができよう。 一方ドデシルピリジニウム基は特殊な第4アンモニウム であるが, 〔R-N 同様強塩基である ${ }^{23)}$ から， $\mathrm{R}-\stackrel{\oplus}{\mathrm{N}} \Longleftarrow$ 強い。また第 2 置換基をもたない上，吸着原子 $\mathrm{N}$ を含む 6 員環は平面構造をとることなどから，この添加剤には 立体障害はありえず, Hackerman らのいう吸着面積の 大きさにも効いてくる*。したがってこのドデシルピリ ジニウム基添加の場合にのみすぐれた吸着効果が現われ て，スズの結晶成長を抑えて結晶核発生速度を增し電析 物の粒度を細くするととすに結晶がいわゆる塊状を呈す る（写真 2，3）とい5，良好な電着結果が得られたも のと考㝋られる。Nを含む6員環にメチル基の入ったド

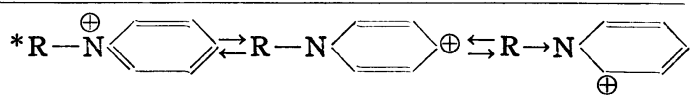

なる共鳴効果により，一層との効果が強められる。 
デシルピコリニウム基の場合， 6 員環が平面構造をとる ためほとんどメチル基の影響は現われず，ドデシルピリ ジニウム基の場合と浪添同様電着によい結果をもたら したが，C.D.を $2.4 \mathrm{~A} / \mathrm{dm}^{2}$ まで上げるととの立体障害 そよるためと思わ礼る影響が出て，若干の針状結晶が認 められた。一般に $\mathrm{R}-\mathrm{N}$

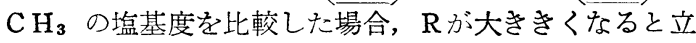
体障害のため後者の方が弱くなるともいわれておりり年， この結果はそれをうらづけている。

な扮電解電位において，無添加剤浴の場合 $-0.528 \mathrm{~V}$ と比較的貴飞現われている理由は, 電着スズが太い針状 結晶のために真の C. D. 汭小さくなっていることが考学 られ、またトリメチルドデシルー,トリメチルヘキサデシ ルー,トリメチルオクタデシルー，ベンジルドデシルー， アンモニウム基など添加の場合，いずれも卑となってい るのは,それらの電着面ぶ非常に細い針状結晶であるた め真の C. D. 方前者よりも大きくなっていることによる と考えられる。そのためこれらの結果は,結晶核生成速度 と過電圧の関係すなわち律速過程の如何にかかわらず過 電圧が增すほど結晶核生成速度が增すという関係 ${ }^{11), 25)}$ を満足しない。しかし密着性良好なドデシルピリジニウ ム基添加の場合はこの関係を満足していて，その添加が 結晶核発生を促進させていると理解される。

\section{5. 結言}

スズ電解精錬用の電解浴について，簡単な浴組成で密 着性のよい電着スズを得ることを目標に, 塩酸々性塩化 スズ浴とそれへの各種カチオン界面活性剤添加について 検討し，ドデシルピリシニウムクロライド添加浴を開発 することと成功し，またこの添加剤の作用効果と機作飞 ついて考察を行なった。要点はつぎのようである。

1. $0.1 \mathrm{M} / l-\mathrm{SnCl}_{2}, 0.25 N-\mathrm{HCl}$ の組成浴で密着性 良好なスズ電着が得られたが，実用浴としては C.D.が $0.16 \mathrm{~A} / \mathrm{dm}^{2}$ と非常に小さいことが点とされた。

2. 上記塩酸々性塩化スズ浴に添加剤としてカチオン 界面活性剤を加元た $0.1 \mathrm{M} / l-\mathrm{SnCl}_{2}, 0.5 N-\mathrm{HCl}, 0.5$ g/1-dodecylpyridinium chlorideの組成浴では, C. D. を $2.4 \mathrm{~A} / \mathrm{dm}^{2}$ と高電流密度にしても電流効率がよく, しかも密着性良好で平坦なスズ電着が得られた。
3. ドデシルピリジニウムクロライドの添加効果の機 作としては, $\mathrm{CH}_{3}\left(\mathrm{CH}_{2}\right)_{11}-\stackrel{\oplus}{\mathrm{N}}$ — 第 2 置換基をもたないこと，吸着原子が平面構造をとる 6 員環中に含まれていることなどが考察された。

(1968-8-1受理)

\section{文献}

1) P. R. Pine, Trans. Electrochem. Soc., 80, 631 (1941)

2) T. Rocksch, ドイツ特許，370194，376775(1922)

3) C. L. Mantell, TIN, The Chemical Catalog Co. Inc., (1929)

4) 向, 日鉱, 74, 104(1958)

5）土肥他，本誌，13，515(1962), 14, 406, 481 (1963), 15, 385(1964), 16, 293(1965)

6) 小浦, 向, 日鈗, 投稿中

7) Metal Finishing Guidebook Directory, Finishing Publication, Inc., p. 331 (1955)

8) 龟山, 電気化学の理論及応用, 中巻 p. 268(1958)

9）無機化学全書, XII-1-1，(1963, 丸善)

10) 外島, 基礎電気化学, (1965, 朝倉書店)

11) J. M. West, Electrodeposition and Corrosion Process, D. Van Nostrand Co. Ltd., London, (1965)

12) 桜井他, 応用界面化学, p. 132 (1967, 朝倉書店)

13）ととば C. A. Mann,et al., Ind. Eng. Chem., 28, 159 (1936)

14) N. Hackerman, et al., ibid., 46, 523(1954)

15) J. A. Crossley, et al., Electrochimica Acta, 11, 1153 (1966)

16) W. Machu, Trans. Electrochem. Soc., 72, 333 (1937)

17) 藤井, 電化, 24, 156 (1957)

18）たとえばフィーザー有機化学, 上巻, 中西訳, (1963, 丸善)

19) N. Hackerman, et al., Corrosion, 11, 249 t (1955)

20) C. C. Nathan, ibid., 12, 161 t (1956)

21) L. W. Jones, et al., ibid., 11, 217t(1955)

22) I. W. Wark, et al., Trans. AIME, 112, 189 (1934)

23）ブルータス有機化学, 下巻, 中西訳, 東京化学 同 人, p. 822

24) 岡本, 有機反応機構, 東京化学同人, p. 40

25）前田, 電極の化学, p.284（1966, 技報堂）

\section{「研究」および「研究ノート」論文募集}

本協会会員各位は本会誌「研究」拉よび「研究ノート」闌へ投稿することができます。 現在研究を進めていられるもの，また，すでに研究を終えられたものに関し，本会投稿規定によりご 投稿下さい。 